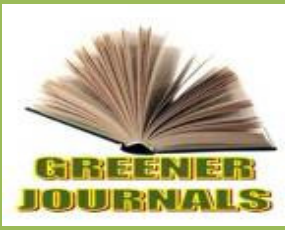

\title{
Study on the Effect of Aqueous Extract of Pterocarpussoyauxii (Oha) on Some Haematological and Haemostatic Mechanism of Male Albino Wister Rats
}

\section{Oguwike F.N. ${ }^{*}$, Nwafia W.C, Etoniru I.S, Oguwike E.R.C}

${ }^{1}$ Dept. of Physiology, Faculty of Basic Medical Sciences, Chukwuemeka Odumegwu Ojukwu University Uli Campus Anambra State.

2 Dept. of Anatomy, Faculty of Basic Medical Sciences Chukwuemeka Odumegwu Ojukwu University Uli Campus Anambra State.

${ }^{3}$ Dept. of Medicine and Surgery, College of Medicine, Chukwuemeka Odumegwu Ojukwu University Uli Campus Anambra State.

\section{ARTICLE INFO}

Article No.:010618001

DOI: 10.15580/GJMS.2018.1.010618001

Submitted: 06/01/2018

Accepted: 10/01/2018

Published: 27/01/2018

*Corresponding Author

Oguwike F.N.

E-mail:foguwike@gmail.com

Phone:08037791363

Keywords: Haemostasis, Platelet, Pteridocarpussoyauxii, haemoglobin, white blood cell, coagulation, and clotting time
The study on the haemostatic and haematological effect of leaf aqueous extracts of pterocarpus soyauxii (Oha vegetable) was investigated.

Sixteen (16) albino wistar rats weighing $200-250 \mathrm{~g}$ were divided into two (2) groups. Group 1 (8 rats) served as control group while Group 2 (8 rats) were the test rats. The control groups were given normal rat pellets and table water while the test groups were given $1.0 \mathrm{ml}$ of the extracts for 30 days.

At the end of the feeding for 30 days, blood samples were collected from the animals by cardiac puncture for haematological analysis while cuts were made on their hairless tail for bleeding and clotting times.

Results from the analysis showed a marked decrease $(P<0.05)$ of haemoglobin concentration, packed cell volume, and platelet counts. The bleeding and clotting times, Prothrombin and Partial thromboplastin time kaolin were prolonged in the test animals. It could be concluded that the consumption of P.soyauxii vegetable has an adverse effect on the haemostatic and haematological indices of albino wistar rats. 


\section{INTRODUCTION}

Pterocarpus soyauxii also called barwood or African coral wood is a perennial non-climbing tree growing 27$34 \mathrm{~m}$ tall with a trunk diameter of up to $1 \mathrm{~m}$ and a flaky reddish grey bark. The leaves are pinnate with 11-13 leaflets. The flowers are produced in clusters. The fruit is a thorny pod 6-9m long which does not split open at maturity (ILDIS,2005). The leaves are edible. They are eaten as vegetable. The wood is valuable and durable; red at first, becoming purplish-brown oilon exposure to light, with a density of $0.79 \mathrm{~g} 1 \mathrm{~cm}^{3}$.The wood is also used in string instruments because of its tonal attributes and durability.

\section{Nutritional and Medicinal Benefits of Pterocarpus soyauxii}

Pterocarpus soyauxii though a natural tree to central and tropical West African countries has an edible leaves which contains vitamin $\mathrm{c}$, and so are eaten as vegetables. The bark extracts are used in herbal medicine to treat skin parasites and fungal infections.

Other nutritional properties of pterocarpus soyauxii include possession of iodine, copper, iron, calcium, magnesium, zinc, sodium, protein and selenium. lodine is most critical to metabolism and overall health than other micro-ingredients. It is unique among the required trace elements because it is the constituents of the thyroid hormones. lodine deficiency is a common cause of preventable mental defects (Hetzel, 1989; Hetzel and Welby, 1997).

Humans naturally receive their iodine by consuming plant and animal products. The intake of iodine generally corresponds to the amount entering the local feed chain from geochemical environment and it is normally low from natural feeds. For the proper utilization of iodine for thyroid hormone synthesis, some minerals are required at the right concentration preparation. The mineral nutrients are inter-related and balanced against each other in human physiology. They cannot be considered as a single element with circumscribed functions. For instance, sodium, calcium, magnesium and phosphorous serve individual and collective purposes in the body fluid regulation.

Inadequate mineral intake generally produces deficiency symptoms which include anaemia, impaired healing of wounds, and delayed blood clotting, severe diarrhea and chronic renal failure. Selenium and iodine ingestion have to be regulated as deficiency can lead to extreme fatigue, endemic goiter, cretinism and recurrent miscarriages (Vanderpas et al, 1990).

Calcium ions are involved in blood clotting, nerve impulse transmission, muscle contraction. Dairy products are very good sources of calcium, green vegetables are good sources also but the presence of oxalic acid for example in spinach renders or makes it non-absorbable(Wardlaw etal, 2004).the calcium in cereals is not also readily absorbable because it is tightly bound to inositol hexaphosphate.

The aim of this study is to determine the effects of the aqueous extract of Pterocarpus soyauxii on haemoglobin concentrations packed cell volume, white blood cell count, clotting time, bleeding time, prothrombin time and partial thromboplastin time Kaolin.

Haemostasis is defined as the arrest or stoppage of bleeding (Guyton and Hall, 2001). It involves the physiological processes of blood vessels. When a blood vessel is injured, the injury initiates a series of reactions resulting in haemostasis. This occurs in three stages namely vasoconstriction, platelet plug formation and coagulation of blood. Immediately after injury, the blood vessel constricts and decreases the loss of blood from damaged portion. The endothelium is damaged and the collagen is exposed. The platelets adhere to this collagen and get activated. This secretes serotonin and other vasoconstriction substances which cause constriction of the blood vessels. All the platelets aggregate together and form a loose temporary platelets plug or temporary haemostasis, which closes the vessel and prevent further blood loss. Activator substances from the traumatized vascular wall, from platelet's and from blood proteins initiate the clotting process. Clot begins to develop in 15 to 20 seconds if the trauma to the vascular wall is minor and 1 to 2 minutes if the trauma to the vascular wall is severe.

\section{MATERIALS AND METHODS}

Sixteen male albino wistar rats were randomly selected and kept in a metal cage with iron netting in a laboratory environment. They were kept in the animal house for 14 days to get acclimatized to the environment before starting an acute feeding with the extracts for 28 days.

\section{Experimental Design}

Sixteen male albino wistar rats weighing 200-250g were selected and divided into two groups. Groups 1 rat served as control while Group 2 rats served as test rats. Group 1 rats were fed with normal rat feed and water ad libitum while Group 2 rats were fed with rat feed in addition to the oral administration of $1.0 \mathrm{ml}$ of the leaf extract of Pterocarpus and water ad libitum.

\section{Preparation of Extracts}

Leaves of Pterocarpus soyauxii were bought in Egbu market near the University botanical garden and it was identified by a botanist in the Botany Department of the University. The botanical identification and authentication was confirmed by a botanist from the Biological science department Chukwuemeka Odumegwu Ojukwu University. (Former Anambra State University) Uli Campus. 
The crude extract was prepared according to the method described by Obiefuna et al (1998). The dried leaves of $p$. soyauxii were oven dried at $45^{\circ} \mathrm{c}$ and $100 \mathrm{~g}$ of the dried leaves was pulverized and soaked for 72 hours in $800 \mathrm{mls}$ of distilled water. It was then filtered with whatman No.1 filter paper and the residue discarded. The filtrate was subsequently evaporated to dryness in an aerated oven at $45^{\circ} \mathrm{C}$. The resulting slurry was stored in closed cab bottles until used. $5 \mathrm{mg} / \mathrm{g}$ of the slurry was prepared and used for oral administration of the test animals in Group 2.

\section{Phytochemical Analysis of Leaves}

The leaves of the plant were screened for the presence or absence of various secondary metabolites using standard phytochemical screening procedures as described by Harbourne (1973), Trease and Evans (1996) respectively. The extracts were tested for glycosides, flavonoids, alkaloids, acidic compounds, resins, fats and oil, carbohydrate and steroid.

\section{Toxicity Study}

The lethality dose of the extract of $P$. soyauxii in albino rats was determined using Lorke's method (1983).

\section{Obtaining a Blood Sample for Tests}

At the end of 30days administration of the crude extract, $0.02 \mathrm{ml}$ of sodium turpentine was injected intraperitoneally into the rats to anaesthetize them. Bleeding and clotting time test were carried out on the animals. After that, $5.0 \mathrm{mls}$ of blood samples was collected by cardiac puncture and expressed into anticoagulant tubes (EDTA tubes, and sodium citrate tubes) and in plain bottles for haematological and haemostatic analysis.

\section{Haemotological Studies}

Haemoglobin estimation was determined by method described by Baker et al, 1998. The packed cell volume estimation was estimated by method of Alexander et al, 1993. The platelet count was done with the method described by Brecher and Cronkite (1950) while the whole blood clotting time was determined using the method of Lee and White (1998), and the bleeding time was carried out as described by Dejana et al (1987). The Prothrombin time and the partial Thromboplastin time kaolin tests were carried out as elaborated in Quick's one stage method (1998).

\section{Study on Effects of the routes of administration on rats}

a) Enteral:Oral administration of the aqueous extracts of $p$. soyauxii to the rats for 30 days was carried out by intubation and the control rats were given normal rat diet during this period.

\section{Effects of Pterocarpus soyauxii on Clotting Time of Rats}

In this study, partial thromboplastin time kaolin and prothrombin time (PT) were done to establish the possible pathway of the action of the extract. The concentration of extract used was $5 \mathrm{mg} / \mathrm{g}$.

The weight of the control animals, their prothrombin time, partial thromboplastin time kaolin, clotting time, bleeding time, and full blood count were determined alongside with test animals before the administration of the extract to the test animals.

At the end of the thirty days feeding, their weight, full blood count (FBC), bleeding time, clotting time, platelet count, prothrombin time (PT) and partial thromboplastin time kaolin (PTTK) tests were carried out again.

\section{Statistical Analysis}

The results obtained in the study were presented as mean and standard deviation. (Mean \pm S.D) and ANOVA was done using the students' $t$ - test to determine the level of significance.

\section{RESULTS}

Table 1:The phytochemical analysis of $P$.soyauxii

\begin{tabular}{|l|l|l|l|l|l|l|l|}
\hline \multicolumn{2}{|c|}{ Constituents in extract of P. soyauxii } \\
\hline & Calcium & Carbohydrate & Alkaloids & Tanins & Saponins & $\begin{array}{l}\text { Fats } \\
\text { \& oils }\end{array}$ & $\begin{array}{l}\text { Terpenoids Sugar, } \\
\text { Acidic compound, } \\
\text { Flavenoid }\end{array}$ \\
\hline $\begin{array}{l}\text { Degree of } \\
\text { concentration }\end{array}$ & +++ & ++ & - & ++ & - & + & - \\
\hline
\end{tabular}

- Negative (absent), + Present in small concentration

++ Present in moderate high concentration

+++ Present in very high concentration 
Table 2: Haemostatic and haematological indices of albino wistar rats before the administration of extracts and thirty (30) days after the administration of P.soyauxii

\begin{tabular}{|c|c|c|c|c|c|c|c|}
\hline Extracts & $\begin{array}{l}\mathrm{Hbg} / \mathrm{dl} \pm \\
\text { S.D }\end{array}$ & $\begin{array}{l}\text { PCV \% } \pm \\
\text { S.D }\end{array}$ & $\begin{array}{l}\text { Platelet } \\
\text { count X10 } \pm \\
\text { S.D }\end{array}$ & $\begin{array}{l}\text { Bleeding } \\
\text { Time (min) } \pm \\
\text { S.D }\end{array}$ & $\begin{array}{l}\text { Clotting Time } \\
\min \pm \text { S.D }\end{array}$ & $\begin{array}{l}\text { Prothrombin } \\
\text { Time see } \pm \\
\text { S.D }\end{array}$ & $\begin{array}{l}\text { Partial } \\
\text { Thromboplastin } \\
\text { Time see } \pm \text { S.D }\end{array}$ \\
\hline $\begin{array}{l}\text { Control rat } \\
\text { Grp. } 1 n=8 \\
\text { (Extract free) }\end{array}$ & $13.9 \pm 0.2$ & $41.2 \pm 0.4$ & $194+30$ & $2.6+0.1$ & $5.3 \pm 0.2$ & $10.4 \pm 1.0$ & $31 \pm 0.6$ \\
\hline $\begin{array}{l}\text { Test Rats } \\
\text { Grp } 2, \mathrm{n}=8 \\
\text { Day } 1 \text { before } \\
\text { extract }(P . \\
\text { soyauxiiadmin })\end{array}$ & $13.7 \pm 0.6$ & $41.0 \pm 1.2$ & $188 \pm 18$ & $2.8 \pm 0.3$ & $5.3 \pm 0.3$ & $14 \pm 0.5$ & $30 \pm 0.4$ \\
\hline $\begin{array}{l}\text { Grp 2: } 30 \text { days } \\
\text { after extract } \\
\text { ( } P \text {. } \\
\text { soyauxiiadmin) }\end{array}$ & $10.4 \pm 0.2$ & $31.2 \pm 0.3$ & $140 \pm 21$ & $10.7 \pm 0.5$ & $12.0 \pm 0.7$ & $24 \pm 0.5$ & $59 \pm 3.0$ \\
\hline$P$ value & $\mathrm{P}<0.05$ & $P<0.05$ & $P<0.05$ & $P<0.05$ & $\mathrm{P}<0.05$ & $P<0.05$ & $P<0.05$ \\
\hline
\end{tabular}

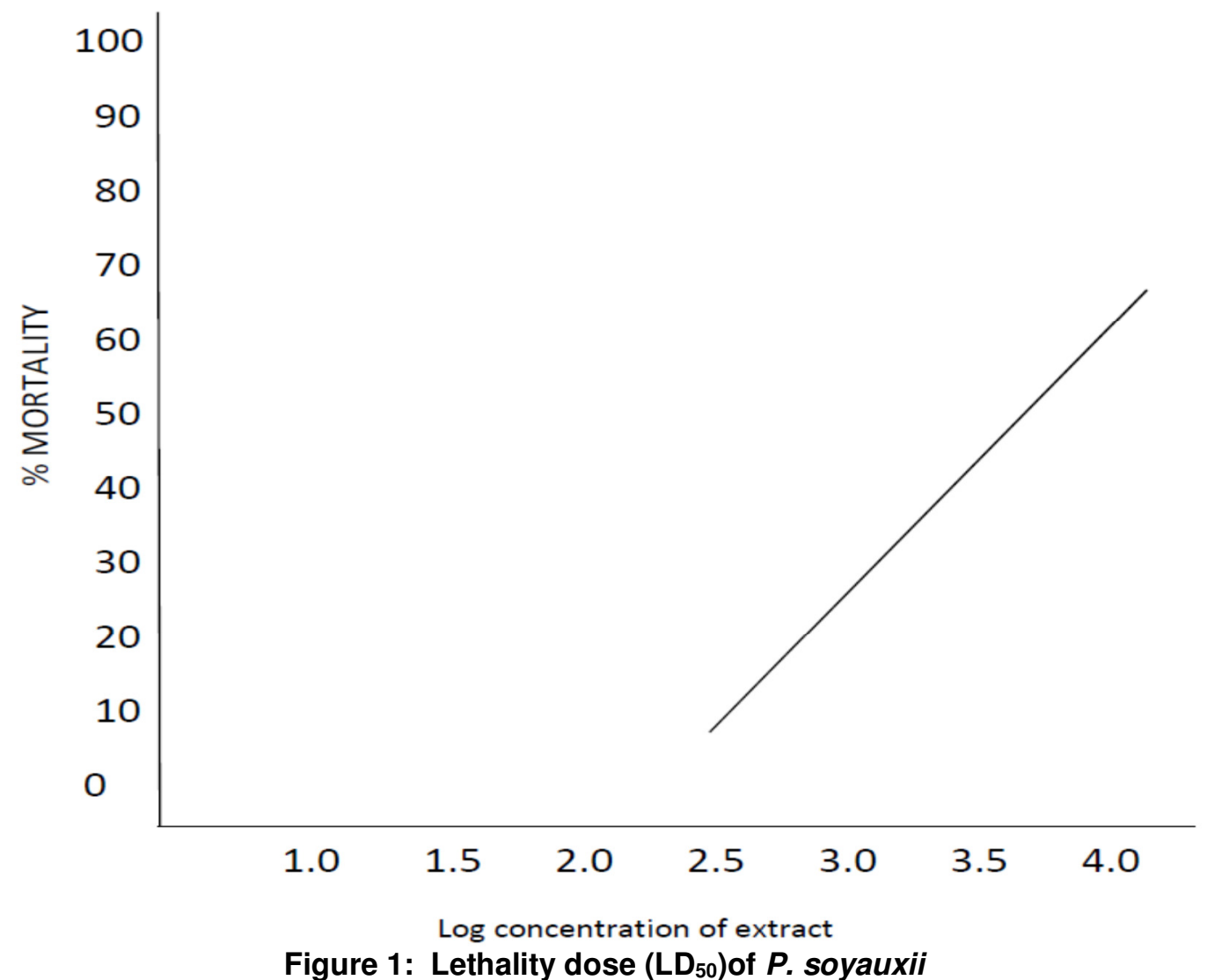

\section{DISCUSSION}

The effect of pterocarpus soyauxii extract on the haemostatic and haematology profile of male albino wistar rats has been assessed. Haemostasis involves the physiological process of blood coagulation and contraction of blood vessels and crude extracts of certain plants could hasten or delay haemostatic processes. In this study, it was indicated from the phytochemical studies there is presence of a typical 
plant constituents (Okoli 2007) such as calcium, carbohydrates, tannins, fats and oil while other constituents such as flavonoids, alkaloids, reducing sugar, terpenoids, steroids acidic compounds were absent. The acute toxicity indicates that $p$. soyauxii extract was non -toxic and the concentration used was safe throughout the period of study. In the phytochemical study, it was observed that the plant lacked alkaloid (protein precipitant) that could have assisted calcium ion (protein precipitant) in the precipitation of coagulation factors(Taofeeq et al, 2005) which promotes clotting in rats.

Visualizing the values of the full blood count and coagulation profiles of the test wistar rats in figure Table 2 , it can be seen that the values obtained in the rats after 30 days feeding on the extract of Pterocarpus soyauxii were reduced compared with their corresponding controls.

Some in organic nutrients may have interfered with the metabolism of the iron contained in the extract. Iron plays an important role in many parts of the body, including immune function, cognitive development, temperature regulation, energy metabolism and work performance. Some iron rich foods are poor sources of this mineral because other compounds render it nonabsorbable. Most contain considerable oxalate, which chelates iron and renders it non-absorbable (Lehninger, 1982). The bio-availability of the iron present in a meal depends on its form and the presence or absence of factors that influence absorption (ward law, 1999). Poor iron absorption may have contributed in decrease in haemoglobin concentration and packed cell volume. This condition can lead to anemia if the rats continue to feed on the extract. There was prolongation in the bleeding time, clotting time, prothrombin time and partial thromboplastin time kaolin of rats fed with the extracts of $P$. soyauxii. This observed effect can be due to lack of alkaloid in the phytochemical contents and reduced platelet count hence it presented a very poor haemostaticagent.

\section{REFERENCES}

Alexander R.R and Griffit J.M (1993).Haematocrit in: Basic biochemical methods $2^{\text {nd }}$ Ed. JOHN WILLEY and SONS INC. Publication, New York p186-187.

Baker F.G, Silverton R.E (1998). Haemoglobin measurement. Introduction to Medical Laboratory Technology.Butter worth Publication Woburn London p358.

Brecher L and Cronkite M (1950).Platelet counts in: Dacie J.V Ed, Basic Heamatological techniques in Edinburgh London Melbourne.
Dejena E, Villa S, De Gactano G (1982). Bleeding time in rats.A comparison of different experimental conditions. Thrombi. HAEMOSTAT 48:108-111.

Guyton A.C and Hall J.E, (2006). Hemostasis and Blood coagulation.Textbook of Medical Physiology $11 \mathrm{ed}$. Elsevier Publications a division of Reed Elsevier India. Private Limited, 17-A/L Main Ring Road LAJPAT NAGAR- iv New Delhi- 110024, India. Pp 457- 464

Harbourne J.B.C (1973). Phytochemical method, Chapman and Hall, London p269.

Hetzel B.S, (1989). The story of iodine deficiency, $1^{\text {st }}$ edition, Oxford Medical Publications.Great Britain p.3.

Hetzel B.S, Wellby M.L, (1997). In "Hand book of Nutritional Essential Minerals".(B.L.O Dell and R.A Sunde, Eds).Marecel Dekker, Inc, Newyork P557.

International Legume Database and Information Service (Ildis),

PterocarpusSoauxii(http;//www.Idris.org/Legume Web?).

Lee L and White W (1985). Investigation for Haemostatic abnormalities. Introduction to Med. Lab Technology $6^{\text {th }}$ Edition Butter worth Publication Woburn p346.

Lehringer A.L, (1982). Principles of Biochemistry $2^{\text {nd }}$ edition.Worth Publishers, New York.

Lorke D, (1983). A new approach to practical Acute Toxicity Testing. Arch. Toxicol 54:276-276.

Obiefuna P.C.M, Owolabi O.A, Adegunle B.J Obiefuna I.P and Sofola O.A (1998). Peta extract of Hibiscus SABDARIFFA produce relaxation of isolated aorta.

Okoli C.O, Akah P.A, Okoli A.S, (2007). Potentials of leaves of Aspillia Africa (compositae) in wound cave: An experimental evaluation. B.M.C complement.Allern Med. 2007:7:24. Published online 2007, July 10: Doi: 1011 86/1472.24, 2007. OKOLI et al: License Boomed Central LTD.

Quicks W, (1985). Basic Haematological techniques in: Practical haematology $6^{\text {th }}$ Edition. Churchill Livingstone, London Melbourne p43.

Taofeeq, Oyeniyi M.A, Tesleem A.O, (2005). Mechanism of Actions of Jetropha gossypifoli Stem latex as a Haemostatic Agent.

Vander A, (2001). Human Physiology, $8^{\text {th }}$ ED. Boston: McGraco-Hill.

Vanderpas J.B, ContempreB, Duale M, Goosens W, Bebe N, Thorpe R, Ntambue K, Dumont J, Thilly C.H, Diplock A.T (1990). lodine and selenium deficiency associated with cretinism in Northern Zaire. A.M.Jclin.Nutr.52:1087-1093.

Wardlaw G.N, 1999. Perspective in nutrition $4^{\text {th }}$ edition, MC Grow- Hills, Boston, P472-502. 